\title{
STRUCTURAL AND MORPHOMETRIC STUDY OF SCALES IN PETZEA RUDD (SCARDINIUS RACOVITZAI MÜLLER 1958)
}

\author{
ȘERBAN, C. ${ }^{1,2^{*}}-$ GRIGORAŞ, G. ${ }^{2}$ \\ ${ }^{1}$ Cross-Border Faculty of Humanities, Economics and Engineering (Cahul - Republic of \\ Moldova), "Dunărea de Jos" University, Galați, România \\ 2 "Răsvan Angheluță” Museum Complex of Natural Sciences \\ Str. Regiment 11 Siret nr. 6A, 800340 Galaţi, Romania \\ (phone: +40-236-311-898; fax: +40-236-414-475) \\ *Corresponding author \\ e-mail: cecilia.serban@ugal.ro

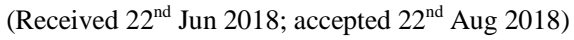

\begin{abstract}
The present study reveals preliminary lepidological results in a critically endangered species, Petzea rudd (Scardinius racovitzai Müller 1958) from Petea Spring Natural Reservation, Bihor county, Romania. Study of scales morphology in Petzea rudd was performed by use of light microscopy. This is the first attempt to reveal some scale features such as: scale type, shape, arrangement and number of radii and position of focus on scale on Petzea rudd. The geometric morphometric analysis has been applied in order to identify the characteristics for a reliable discrimination between Petzea rudd and its related species from Romanian inland waters, common rudd, Scardinius erythropthalmus (Linnaeus, 1758). The comparative analysis of scales shape in S. racovitzai and S. erythrophthalmus highlighted the statistically significant discrimination among two sets of observations and the significant variation of focus position and shape of scales among these two species.
\end{abstract}

Keywords: Petzea rudd, scales, morphology, geometric morphometrics, light microscopy

\section{Introduction}

Petzea rudd, Scardinius racovitzai Müller 1958, is a critically endangered fish species (Freyhof and Kottelat, 2008) that is endemic in Ochiul Mare Thermal Lake from the Petea Spring Natural Reservation, Bihor county, from Western part of Romania (Müller, 1958; Bănărescu; 1964; Kottelat and Freyhof, 2007). The present-day status of thermal ecosystem is strongly deteriorated and exposed to extinction because the over exploitation of the thermo-mineral underwater springs and decreasing of thermal water flow (Telcean an Cupşa, 2013; Grigoras et al., 2014; Müller et al., 2014b).

The taxonomic status of $S$. racovitzai was differently approached by ichthyologists, after first description as specific taxon by Müller (1958). Thus, S. racovitzai was described as subspecies of the cosmopolite common rudd, S. erythrophthalmus (Linnaeus, 1758) by Bănărescu (1964) while further studies revealed specific morphological, physiological and ethological patterns of Petzea rudd (Crăciun, 1998, unpublished PhD dissertation quoted by Bănărescu, 2002; Crăciun, 1997; Müller et al., 2014a; Grigoras et al., 2014, 2015). The species is indexed with specific rank, as $S$. racovitzai by Kottelat and Freyhof in 2007. Bănărescu (2002) supposed S. racovitzai could be a recent isolated species from Central European common rudd and he considered that molecular techniques are necessary for clarifying the taxonomic status of Petzea rudd. 
The present study provides preliminary results regarding morphology of the $S$. racovizai scales. To the best of our knowledge, this is the first attempt to study the scales morphology in thermal rudd from Natural Reserve of Petea Spring.

A second objective of the paper is to assess the scales morphometric patterns that can be used for discrimination of Petzea rudd from its congener species from Romanian inland waters, S. erythrophthalmus. The disruption of the thermal barrier which separated in the past the Petzea rudd from the related species (Telcean and Cupșa, 2013) raises the question of continuity for thermal population under the conditions of cohabitation with a more opportunistic species with hybridisation potential (Nico et al., 2015). We have applied principal components analysis for examination the particularities of shape variation in scales samples (Klingenberg, 2011). Canonical variate analysis (CVA) provides information that maximizes the separation of species (Klingenberg, 2011). We also used the discriminant analysis (DA) for reliability testing of groups dissimilarity (Klingenberg, 2011).

\section{Literature review}

Research of fish scales represents a useful tool for identifying the fish at genus or species levels and also in studies of fish phylogeny, sexual dimorphism, age determination, evaluation of the habitats impact on development etc. (Cărăușu, 1952; Esmaeili et al., 2007, 2009; Esmaeili and Gholami, 2011; Ibáñez et al., 2007, 2016; Jawad, 2005a, 2005b; Jawad and Al-Jufaili, 2007; Masood et al., 2015; Miranda and Escala, 2000; Poulet et al., 2005; Renjith et al., 2014).

Shape, size and number of scales are characters used in the taxonomy of fish (Bănărescu, 1964). Since the beginning of the $19^{\text {th }}$ century, Agassiz used a classification system of the fish into four groups, based upon scale morphology (Esmaeili et al., 2009; Renjith et al., 2014). Likewise, the presence or absence of the denticles as well as their shape, size and the distances between them can be utilised as taxonomy analysis criteria in various fish species (Esmaeili et al., 2007, 2009; Jawad, 2005a, b; Delmater et al., 1974; Lippitsch, 1990; Jawad et al., 2007 cited by Esmaeili and Gholami, 2011).

Scale morphology is frequently applied as an instrument of analysis of the differentiation between populations, species or assessment of the phenotypic plasticity of fishes in relation with the habitat conditions and effect of toxic chemicals (Cărăuşu, 1952; Jindal and Jha, 2005; Pillay, 1950; Taylor, 2012).

Deviation from pattern of circuli disposal or discontinuities of circuli, breakage or loss of interradial denticles, deformations or losses of tubercles provide conclusions regarding the past environment under which were exposed the fish, including the effect of pollutants on organism during its development and growth (Esmaeili and Gholami, 2011). Lippitisch (1990) and Pou and Gallego (1990), both quoted by Jawad (2005a) show different environment factors may have an effect on some scales morphological characters. Taylor (2012) mentions the fish populations display different growing characteristics in relation with various external factors, e.g. seasonal or habitat variability, availability of feeding resources etc. and therefore, the scales, that also are the first contact barrier with surrounding environment, represent an important phenotypic particularity in relation with all these factors.

In the same, way, the researches of Cadrin (2000) cited by Taylor (2012) pointed out the geographical isolation may lead to occurrence of some morphological patterns of 
fish scales at population level as a result of environment influence or selection over ontogenetic development, inducing morphometric differentiation between species.

There are studies that highlight the influence of intrinsic factors on the intraspecific differences of scale characters in fish. The lepidological researches of Sire (1986) quoted by Mekkawy et al. (2011) in cichlids as well as the studies of Mekkawy et al. (2011), Mahmoud et al. (2005) and Harabawy et al. (2007) in various wide-spread fresh water and marine species, sustain the genetic determinism of scales morphology, invalidating environment control.

In the research of Müller et al. (2014a), on morphology of scales in S. racovitzai, authors discriminate Petzea rudd population from its congeneric species, common rudd, S. erythrophthalmus, by using geometric morphometrics of scales. Several references regarding the lepidological studies in various cyprinids have been used in the interpretation of our results; Gursoy et al. (2005) in Scardinius erythrophthalmus, Miranda and Escala (2000) and Jawad (2005a) in species of Barbus genus, Poulet et al. (2005) in Leuciscus burdigalensis Valenciennes, 1844, Jindal and Jha (2005) in Cyprinus carpio var. communis Linnaeus, 1758, Esmaeili et al. (2007) in Capoeta damascina (Valenciennes, 1842), Esmaeili and Gholami (2011) in Rutilus frisii kutum Kamenskii 1901, Staszny et al. (2012) in Carassius gibelio (Bloch, 1782).

Statistical tools used in our study for shape variability analysis with the help of shape coordinates (geometric morphometrics) is largely applied in biology researches (Ibáñez et al., 2007; Klingenberg, 2011; Miranda and Escala, 2000; Moneva et al., 2012; Poulet et al., 2005; Staszny et al., 2012).

\section{Materials and methods}

The $S$. racovitzai specimens have been sampled in August and September, 2013 from the "Ochiul Mare" Lake, Natural Reserve Petea Spring, Bihor county, North-Western Romania (Fig. 1 left). The fish sampling was approved by Order no. 1231/2013 of the Environment and Climate Changes Ministry. Different methods have been used for fish capture: a cast-net and a fishing net with 10-16 mm mesh sizes (Fig. 1 right).
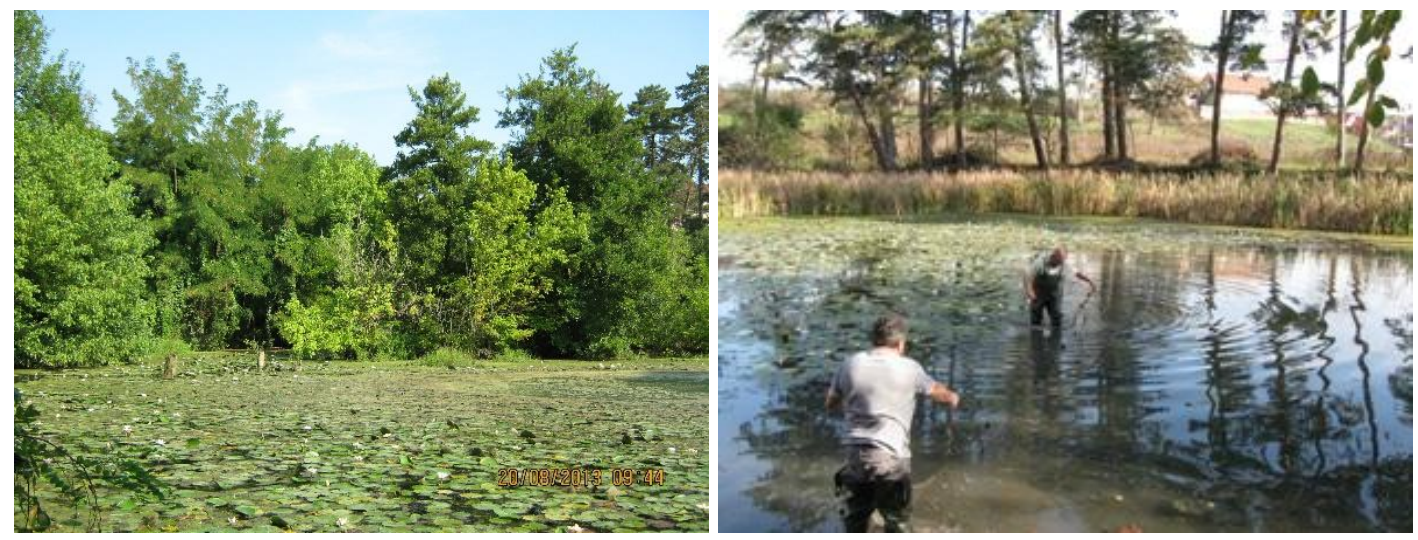

Figure 1. "Ochiul Mare" Lake, Natural Reservation Petea Spring, Bihor county, Romania. The natural habitat of Petzea rudd (left). Fish sampling with fishing net (right)

The scales were removed from the left side of the body, in the area between the dorsal fin insertion and the lateral line (Fig. 2) from thirteen specimens. The small 
number of fish used for this study is linked to the special conservation status of the species and special law of exemption for capture. Around 3-5 scales taken from each specimen have been preserved in dry state and pressed in paper envelopes, after the removal of the epithelium cells and mucus.

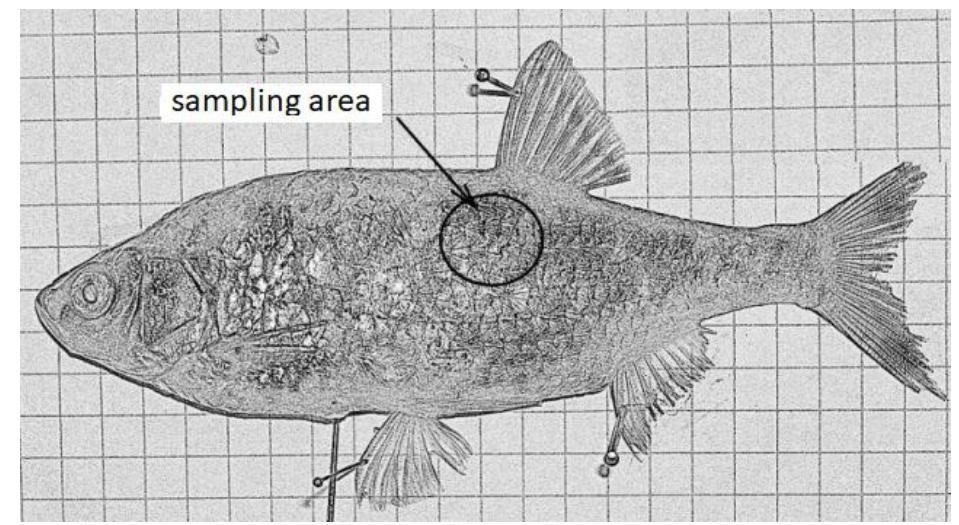

Figure 2. S. racovitzai and the emphasised area of the scales sampling from the fish body

The analysis of scales morphology was carried out between 2 microscope glass slides, under microscope (Olympus $\mathrm{CH} 2$ ), magnification up to $1500 \mathrm{x}$, for the identification of the structure details.

Scales morphometric patterns (shape and size variation) were used for discrimination between $S$. racovitzai and its congener species from Romanian inland waters. Similar operations of sampling/processing scales where applied in the case of common rudd, $S$. erythrophthalmus. Atotal of fourteen specimens of common rudd have been captured from Lower Danube River in the confluence area with Prut and Siret rivers (Mm80).

A stereo-microscope (Olympus SZ 40-CTV), 10x ocular and 4x maximum focus has been used for images collecting of scales from both species. The images of the scales enlarged through stereomicroscopy where digitised with the camera (Canon A590 IS).

Seven markers were attached on every digital image of the scales using the TPS Digitize (Rohlf, 2016a) (Fig. 3).

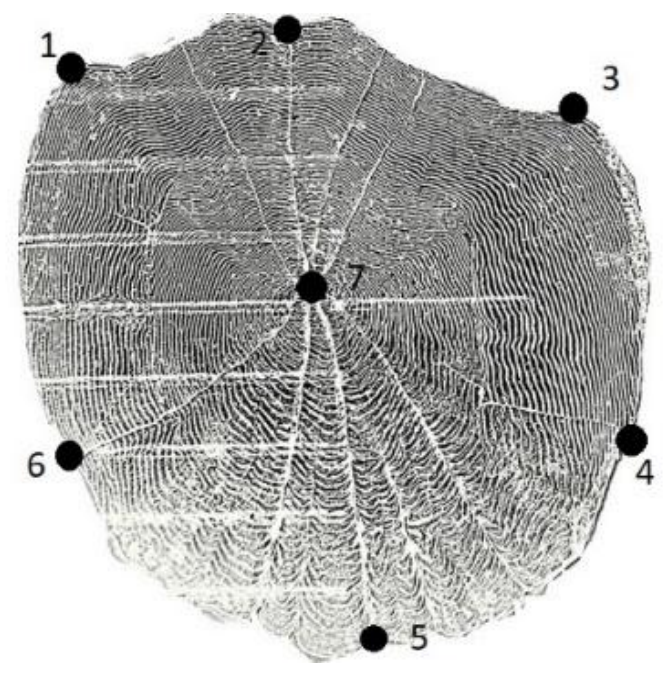

Figure 3. Landmarks data collection on Petzea rudd scale 
The digital images were processed with and TPS Utility (Rohlf, 2016b) software before statistical analyses.

The geometric morphometric analysis of the scales of two congener species where processed with MORFOJ 1.05f software (Klingenberg, 2011). Data regarding the scales shape was obtained by Procrustes superimposition that excludes the variation of size, position and orientation of landmarks. Several statistical tools: the principal component analysis (PCA), discriminant analysis (DA) and canonical variate analysis (CVA) were applied in order to draw conclusions regarding the two groups separation.

\section{Results and discussions}

\section{Preliminary results regarding the scales morphology in S. racovitzai.}

The type of scales from the lateral side is elasmoid cycloid, with general particularities of a cycloid scale (Fig. 4): anterior field (rostral), posterior field (caudal), the focus, radii, circuli, denticles of circuli, tubercles in posterior zone of the scale.
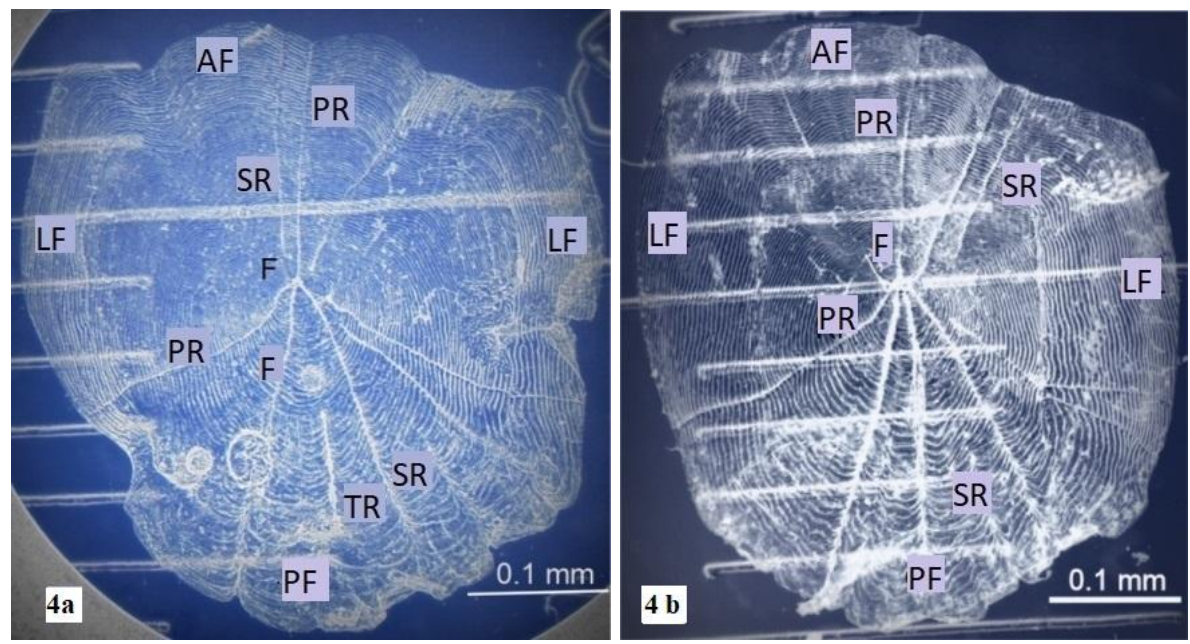

Figure 4. Stereomicroscope images of normal scales from the lateral side of Petzea rudd (10 $x 3$ 3). $a$-scale with all three radii types, $b$ - scale with primary and secondary radii. $A F-$ anterior field, $P F$ - posterior field; $L F$ - lateral field, $P R$ - primary radii, SR - secondary, TR tertiary radii; $F$-focus (nucleus)

The focus or nucleus of the scale (Fig 4, 5a), that occurs during ontogenetic development of fish, can represent a taxonomic criterion (Jawad, 2005a). In $S$. racovitzai, the focus is slightly displaced to front of the scale and divides the scale in anterior field (cephalic towards focus) and the posterior one (caudal towards focus). The focus area appears as a reticulate structure, with a not clear shape delimitation, with or without pore mucus. This aspect is recorded in other fish species scales. Jawad (2005a) mentions similar focus characteristics in another cyprinid, B. arabicus (Trewavas, 1941).

There are interspecific differences regarding the position and shape of scale focus. A pointed shape is observed by Esmaeili et al. (2011) in Rutilus frisii (Nordmann, 1840), a round shape focus in Labeo niloticus (Linnaeus, 1758) by Jawad (2005a), translucent or with mucus pores in Capoeta damascina according to Esmaeili et al. (2007). 


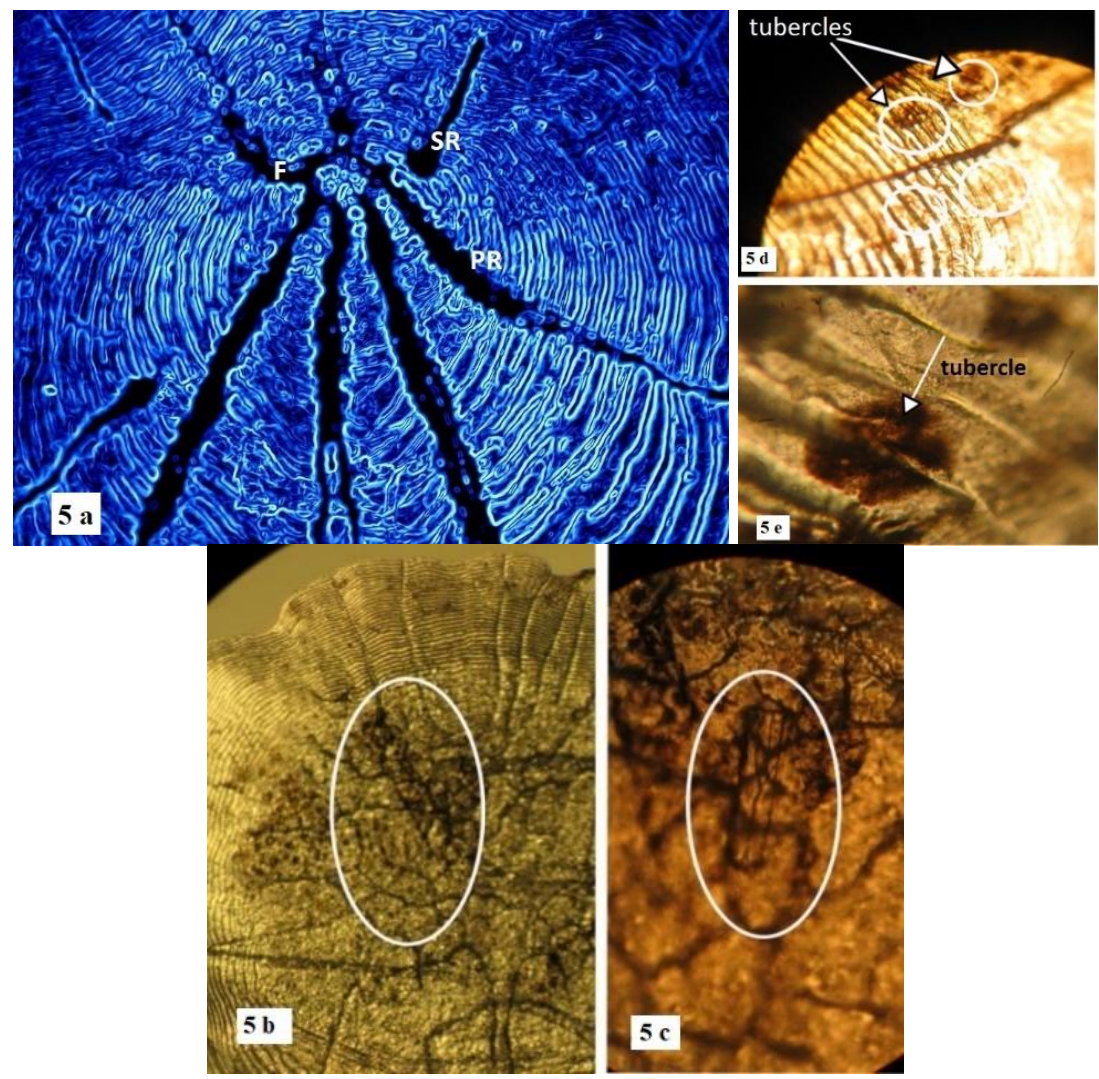

Figure 5. Microscope images of normal scales and lateral lines scales. a-normal scale with reticulate focus (nucleus) and radii that cross the focus and circuli $(15 \times 40), b$-lateral lines scale image revealing the lack of focus and the disposal of lateral line canal along the anterior - posterior axis (10 x 3.5), c - the lateral lines channel with previous pore and posterior pore (15 $\times 10), d$-normal scale with tubercles, $e$-normal scale with tubercle with circular shape from the posterior field ( $15 \times 40)$

The scales from the vicinity of the lateral line have the focus slightly outlined and covered by reticular structures shaped like honeycomb. Hagerman (1952) noted the scale focus of some fish species may gain a diffused appearance as the age increasing.

The same reticulate structures of the focus of scales from the vicinity of the lateral line in Petzea rudd is revealed by Esmaeili et al. (2007) for other cyprinids as Catla catla (Hamilton-Buchanan, 1822) and Tor putitora (Hamilton-Buchanan, 1822).

Microscopic observation in Petzea rudd scales from lateral line revealed the lack of focus (Fig. 5b, c). The same feature is mentioned by Esmaeili et al. (2007) in cyprinid C. damascina. Conversely, other species display the focus in the lateral line scales as is highlighted by Masood et al. (2015) on some mugilid species.

The lateral line canal (Fig. 5b,c) is positioned on the anterior-posterior axis of the scale, slightly oblique and crossing about a half from the anterior scale field, with two pores, the anterior one in a "V" shape and the posterior pore in a "C" shape. The electronic microscopy studies regarding the lateral line scales of various teleost species reveal an increased structural variability of the lateral line canal, which can take different form as straight or oblique simple perforations (Delmater et al., 1973 quoted by Esmaeili et al., 2007) till the wide canals protected by complex structures covering 
two-thirds of the scale on which focus is present (e.g. in Barbus arabicus, Lates niloticus, according to researches of Jawad, 2005a).

Primary radii (Figs. $4,5 a$ ) reach the focus and there are $1-4$ radii in the anterior field and 1-4 radii in the posterior field. The similar results have been reported in other species such as genus Barbus studied by Jawad (2005a). These radii type can converge to the nucleus without crossing it, e.g. in Tripterygiidae as it is shown by Jawad study (2005b). Lateral body scales also have secondary radii, more numerous than the primary ones (0-2 secondary radii in the anterior field of scale, 1-8 secondary radii in the posterior field) and even less tertiary radii ( $0-1$ tertiary radii in the posterior field of scale) (Figs. 4, 5a). We have not identified a significant relationship between the scales size and the number of radii. The studies of Esmaeili et al. (2007, 2009), Esmaeili and Gholami (2011) reveal the number of radii depends upon the location of scales in different body areas and represents a line of scale flexibility. According to these authors as well as Jawad (2007) quoted by Esmaeili et al. (2007), in some teleost fish, there is a proportional relation between the radii number and body length, the radii number could being used as a taxonomic tool for a reliable species identification.

The presence of primary, secondary and tertiary radii could also provide information regarding the growing conditions of fish (environment factors, feeding resources) (Lippitsch, 1990 quoted by Esmaeili and Gholami, 2011). This scale pattern is considered as being linked to quantity and quality of trophic resources, available during development and growing period (Johal et al., 1984 and Tandon and Johal, 1996 cited by Esmaeili et al., 2007; Esmaeili and Gholami, 2011).

Concentric circuli (Figs. 4, 5 and 6) start near the focus area, being interrupted by radii and represent concentric distinctive growth lines, formed through sclerite sedimentation and separation through inter circular space (Fig. 6).
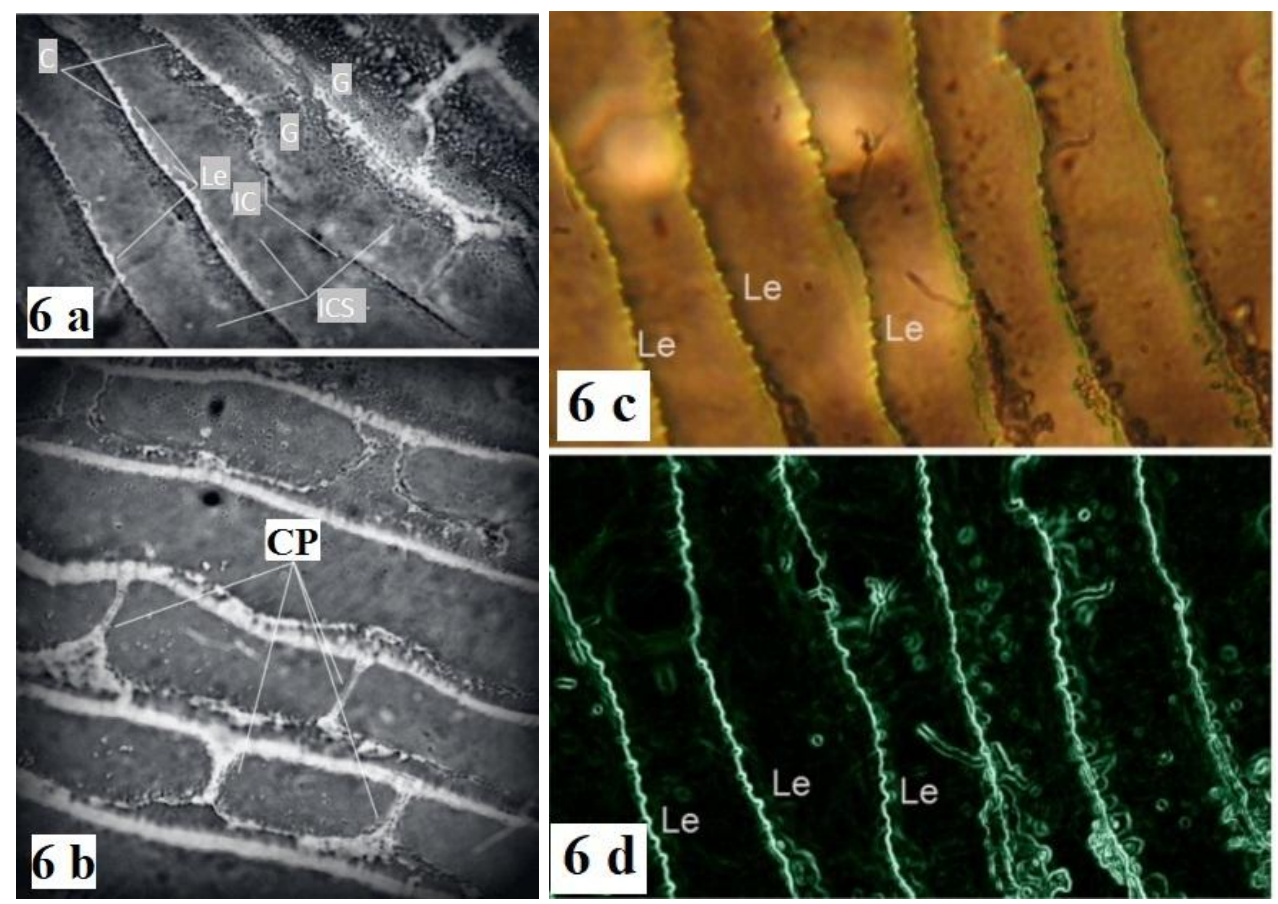

Figure 6. Microscope images of the scales from the lateral side in S. racovitzai (15 x 40). ascale with circuli $(C)$, hyaline intercircular spaces (ICS), interrupted circuli (IC) and inter circular granulations $(G) ; b$-scales with calcium projections $(C P) ; c, d$-scales with denticles or lepidonts on the interradial circuli (Le) 
Inter circular spaces are in general really narrow in the anterior field of scale as a result of the focus position, and wider in the lateral and posterior fields. Similar observations are mentioned by Esmaeili (2011) at Rutilus frisii kutum, the posterior circuli could being less distinctive (Moneva et al., 2012), covered by tubercles or missing in other species such as a cyprinid fish, Capoeta damascina (Esmaeili et al., 2007).

The anterior and lateral interradial circuli are almost rectilinear while these structures are convex in the posterior field. According to Lippitsch (1990) cited by Esmaeili et al. (2007), the shape of the first interradial circuli (rectilinear, convex or concave) could be used in the determination of some cichlid species and can suffer changes under environment factors influence.

The concentric annuli formed around the nucleus, typical for the fish species from temperate zones (Bănărescu, 1964; Cărăușu, 1952; Hagerman, 1952; Ilieș et al., 2014) are difficult to detect in the Petzea rudd, which is not subjected to the same seasonal temperature variation. Appearance false annuli in some observed scales could be linked to other extrinsic or intrinsic factors that can can lead to a variable growing rhythm, e.g. reproduction period (Hagerman, 1952; Gursoy et al., 2005), but this aspect should be further investigated.

The circuli have calcium projections (Fig. 6b), radii bifurcations and specific structures called denticles (lepidonts) (Figs. $5 c, d$ ), the last ones being identified in the lateral field of scale and oriented towards the focus. The presence or absence of the denticles, their shape, size and the distances between them can be utilised as taxonomy analysis criteria in various fish species (Esmaeili et al., 2005, 2009; Jawad, 2005a, b; Delmater et al., 1974; Lippitsch, 1990; Jawad et al., 2007 cited by Esmaeili and Gholami, 2011).

The posterior field of the scales possesses pigmentary granules (tubercles) with regular shape or formless contour (Figs. $5 d, e$ ). The tubercles are formed by crowding of the epithelial cells of epiderma. According to researches of Esmaeili et al. (2007), Esmaeili and Gholami (2011), Ibáñez et al. (2007), these tubercles contribute to the rigour of the scales and represent a useful tool for taxonomic research as well as habitat condition assessment. We noted a poor distribution of the tubercles on the scales. This aspect must be further investigated in order to verify the origin of this observed particularity (genetical or medial effect).

\section{Geometric morphometric analysis of scales in S. racovitzai}

The principal components analysis (PCA) has enabled conclusions regarding the shape variation between fish samples. and was performed by use of the covariance matrix of Procrustes coordinates (Klingenberg, 2011) for each group of the two congener species, S. racovitzai and S. erythrophthalmus. The data of the landmarks were superimposed through a full Procrustes fit.

According to PCA analysis, the first three components sum $70.459 \%$ from total variance (Fig. 7) that reveal significant variation in shape of scales sampled from two rudd groups.

The shape changes of lateral body scales in both species are illustrated in Figure 7. The focus position (represented trough the L7 landmark, Fig. 8) in S. racovitzai, is displaced prior from the centre of the scale compared with the S. erythrophthalmus focus disposal and the entire shape is more elongated in Petzea rudd (Fig. 8). One the other hand, the axis represented by the L4-L6 landmarks (which delineates the field 
with tubercles) does not show significant variation of position, being connected with the adaptive phenotypic response of the two related species to similar hydrodynamic feature (Ibáñez et al., 2007; Sudo et al., 2002 cited by Ibáñez et al., 2007).

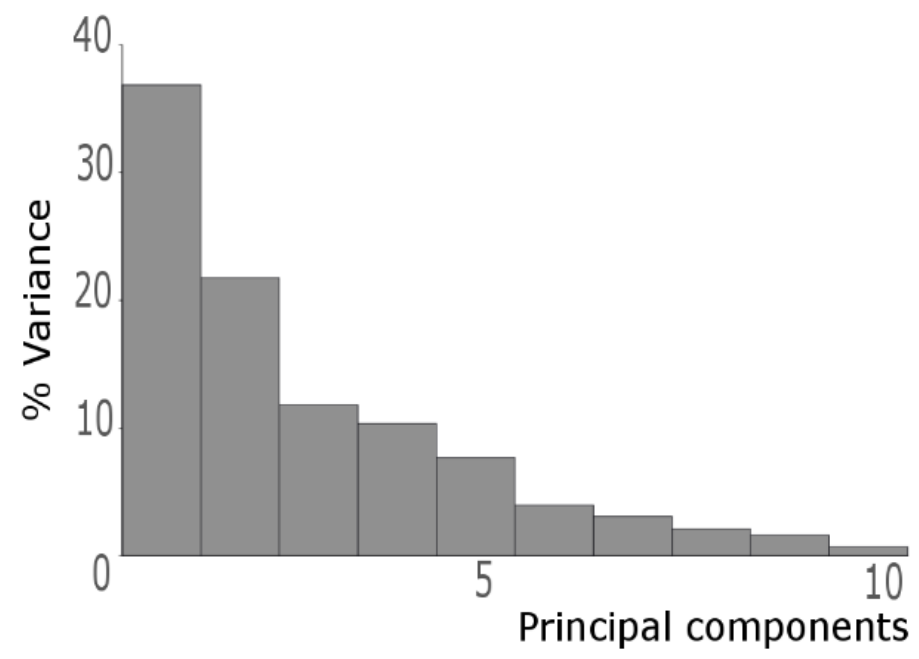

Figure 7. The percentage of total variance for each principal component $(P C)$ of the fish scales analysis of $S$. racovitzai and $S$. erythrophthalmus

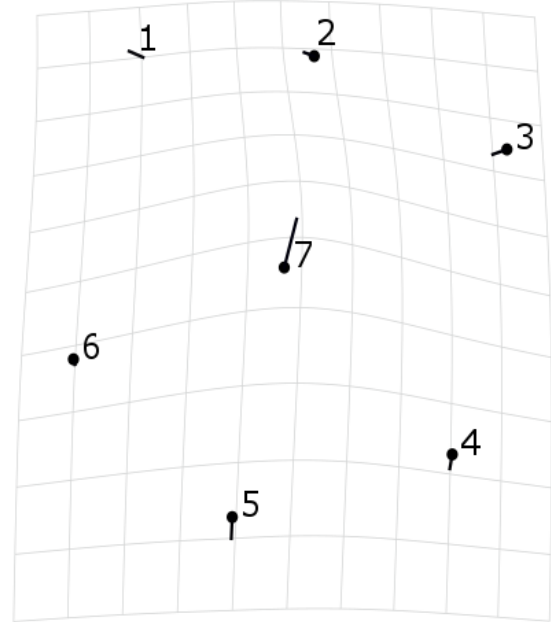

Figure 8. Transformation grid illustrating the scale shape changes associated with PC, between the S. racovitzai and S. erythrophthalmus. The lines point in the direction of the shape change for each landmark

The relationships between observations carried out on scales geometric morphometric analysis and the disposal of the specimens of two species in the multivariate analysis morphospace is shown in Figure 9. The scatter plot of PC scores reveals the two clear groups separated by PC1.

CVA provides extra information in data interpretation that maximise the separation between groups (species/ecotypes, Klingenberg, 2011). The histogram of canonical variate scores covers the shapes particularities which denote the dissimilarities between the two species (Fig. 10). 


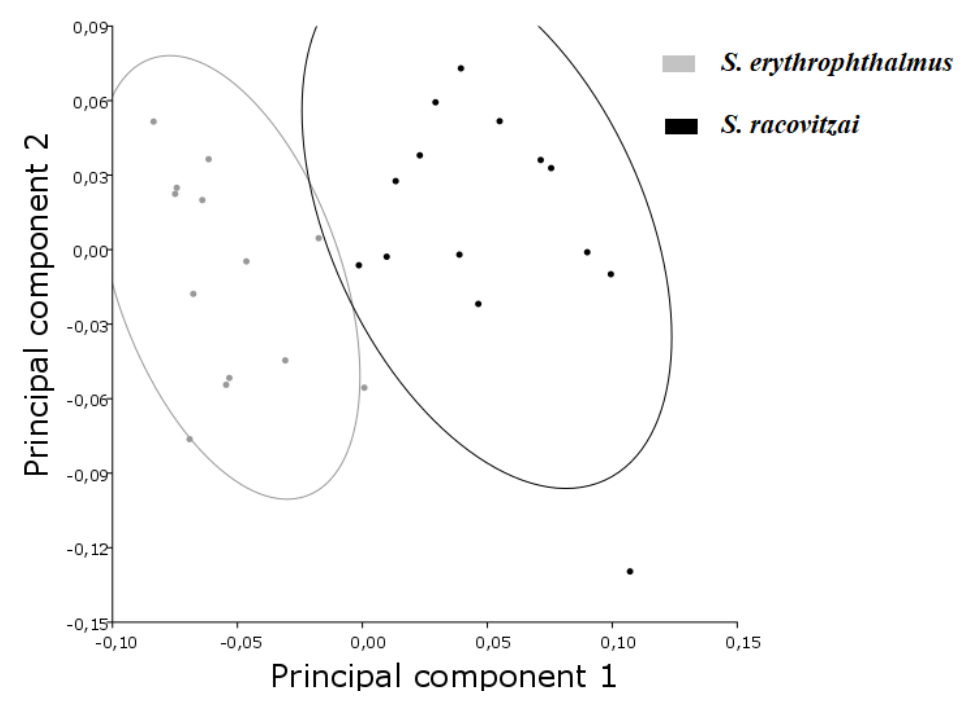

Figure 9. The tolerance limits (90\% confidence level) of the scores distribution of the first two principal components $(P C)$ of the scales shape analysis of fish from two groups. The species disposal in the morphospace of the multivariate analysis (PC1 36.865\%, PC2 21.766\%)

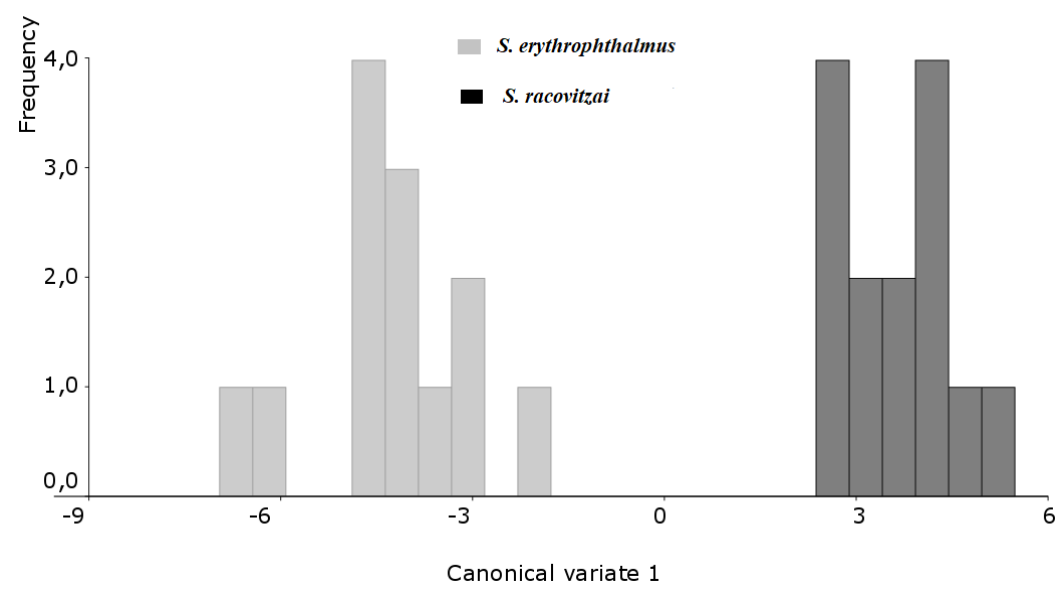

Figure 10. Scatter plot of CV scores for scales shape of two congener species (S. racovitzai and S. erythrophthalmus)

Mahalanobis distance (7.5872) reveals a significant separation between groups ( $\mathrm{P}<0.0001$ from 10000 permutation tests). The same result is obtained by permutation test for Procrustes distances $(\mathrm{P}=0.1067, \mathrm{P}<0.0001)$.

The discriminant analysis (DA) of scales shape of fish from the two groups allows the examination of reliability of separation between groups.

The histogram of distribution of eigenvalues discriminant scores highlighted the separation among the two congener species (Fig. 11).

The parametric P-value $(<0.0001)$ for null hypothesis test of similarity between means of observations groups sustains the reliable distinguish between the rudd species. The results for Procrustes distance (0.10672500), Mahalanobis distance (7.5872) and associated parametric P-values could also be in connection with anisotropy of scales samples (Klingenberg, 2011). 


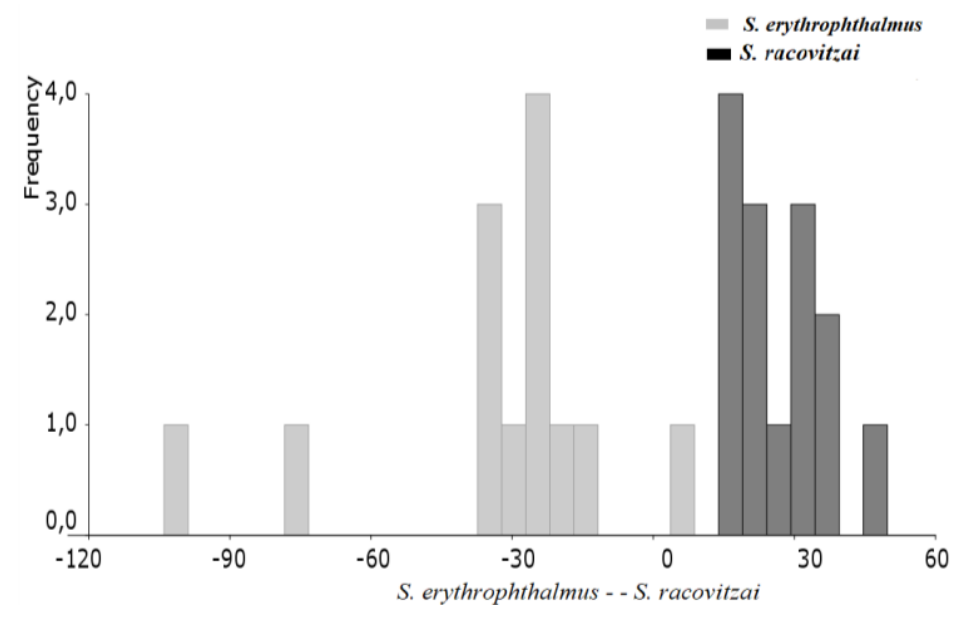

Figure 11. Discriminant analysis of two rudd species using fish scales. Frequencies of discriminant scores predicted by a Mahalanobis distance (leave-one-out) cross-validation are shown using histogram bars

\section{Conclusions}

The microscopic analysis of scale morphology reveals that lateral scales in $S$. racovitzai are of elasmoid cycloid type, with following particularities: anterior field (rostral) and posterior field (caudal), focus, radii, circuli, denticles on the circular radii and tubercles.

Some scale features on Petzea rudd as: the reticulate structure of the normal scale focus, the lack of the focus on lateral line scale, the primary radii crossing the focus, the presence of toward oriented denticles in the lateral fields of scale, displaying of tubercles with regular or formless shape in the posterior field of scale are common with other cyprinids species.

The focus position, slightly displaced to front of scale represents a reliable criterion that discriminate the $S$. racovitzai from the congener species, $S$. erythrophthalmus.

Taking into consideration our preliminary results regarding the morphology of Petzea rudd scales and the pattern that discriminate $S$. racovitzai from $S$. erythrophthalmus, futur comparative works will develop in order to define which scale features clearly distinguish Petzea rudd from other related cyprinids species.

Acknowledgements. The present study was supported by The Mohamed bin Zayed Species Conservation Fund, Abu Dhabi (project no. 13255722 "Captive breeding and maintaining ex situ populations of Scardinius racovitzai and Melanopsis parreyssii"). The authors gratefully acknowledge the following individuals for their support: the anonymous reviewers and the editors of Applied Ecology and Environmental Research for the valuable, critical and helpful comments on the manuscript.

\section{REFERENCES}

[1] Bănărescu, P. (1964): Pisces - Osteichthyes (peşti ganoizi şi osoşi). Vol. XIII. - Fauna R.P.R., Edit. Academiei, București, pp. 53-55 (in Romanian).

[2] Bănărescu, P. (2002): Species and subspecies of fish fauna and lampreys andemic or almost endemic to the drainage area of the river. - TISCIA Monograph Series, Ecological Aspect of the Tisa River Basin, 21-24 March, 2002, 6: 167-172. 
[3] Cadrin, S. X. (2000): Advances in morphometric identification of fishery stocks. Reviews in Fish Biology and Fisheries 10: 91-112.

[4] Cărăușu, S. (1952): Tratat de ihtiologie. - Ed. Acad. RPR, București, pp. 36-46 (in Romanian).

[5] Crăciun, N. (1997): Ethological researches on Scardinius racovitzai from the Thermal Lake 1 Mai, Oradea. - St și Cercet 2: 79-88.

[6] Crăciun, N. (1998): Cercetări de etologie comparată a unor peşti marini şi dulcicoli din fauna României. - Teză de doctorat, Institutul de Biologie al Academiei Române, Bucureşti (in Romanian).

[7] Delmater, E. D., Courtenay, W. R. (1973): Variations in structure of the lateral line canal on the scales of Teleostean fishes. - Z. Morph. Tiere 75: 259-266.

[8] Delmater, E. D., Courtenay, W. R. (1974): Fish scale as seen by scanning electron microscopey. - Biological Sciences 37: 141-149.

[9] Esmaeili H R, Gholami, Z. (2011): Scanning electron microscopy of the scale morphology in Cyprinid fish, Rutilus frisii kutum Kamenskii, 1901 (Actinopterygii: Cyprinidae), Iran. - J Fish Sci 10(1): 155-166.

[10] Esmaeili, H. R., Hojat, A. T., Teimory, A. (2007): Scale structure of a cyprinid fish, Capoeta damascina (Valenciennes in Cuvier and Valenciennes, 1842) using scanning electron microscope (SEM). - Iranian J Sci Tech 31: 255-262.

[11] Esmaeili, H. R., Somayeh, B., Halimeh, Z., Fatemeh, S. (2009): Scales morphology of thank goby Glossogobius giuris (Hamilton-Buchanan, 1822) (Perciformes, Gobiidae) using scanning electron microscope. - J Biol Sci 9: 899-903.

[12] Freyhof, J., Kottelat, M. (2008): Scardinius racovitzai. The IUCN Red List of Threatened Species. Version 2017-3. - www.iucnredlist.org. Accessed on 12 January 2018.

[13] Grigoras, G., Müller, T., Gagiu, A., Bontas, I., Serban, C., Rosca, M. (2014): Ex situ conservation of the thermal rudd (Scardinius racovitzai): a general review of work and results. - Nymphaea (Folia naturae Bihariae) 41: 103-134.

[14] Grigoraș, G., Müller, T., Gagiu, A., Bontaș, I. (2015): Preliminary results regarding the present morphometric characters of Scardinius racovitzai Müller 1958 from Petea Spring Natural Reserve. - Transylv Rev Syst Ecol Res: 79-95.

[15] Gursoy, C., Tarkan, A. S., Acipina, H., Gaygusuz, O. (2005): Validation of the scales age determination in a cyprinid, Scardinius erythrophthalmus (L., 1758). - Int J Zool Res 1(1): 33-36.

[16] Hagerman, F. B. (1952): The biology of the Dover sole, Microstomus pacificus (Lockington). - Fish Bulletin, No. 85, UC San Diego.

[17] Harabawy, A. S. A., Mekkawy, I. A. A., Mahmoud, U. M. (2007): A comparative study on scale characteristics and their functional morphology of four Goatfishes (Family Mullidae) from the Red Sea. - J. Egypt. Soc. Biotech. Environ. Soc. 9: 123-163.

[18] Ibáñez, A. L., Cowx, I, G., O’Higgins, P. (2007): Geometric morphometrics analysis of fish scales for identifying genera, species and local populations within Mugilidae. - J Fish Aquat Sci 64: 1091-1100.

[19] Ibáñez, A. L., Jawad, L. A., Sadighzadeh, Z. (2016): Morphometric variation of fish scales among some species of the family Lutjanidae from Iranian waters. - Cah Biol Mar 57: 289-295.

[20] Ilieş, I., Traniello, I. M., Sîrbulescu, R. F., Zupanc, G. K. H. (2014): Determination of relative age using growth increments of scales as a minimally invasive method in the tropical freshwater Apteronotus leptorhynchus. - J Fish Biol 84: 1312-1325.

[21] Jawad, L. A. (2005a): Comparative morphology of scales of four teleost fishes from Sudan and Yemen. - Journal of Natural History 39(28): 2643-2660.

[22] Jawad, L. A. (2005b): Comparative scale morphology and squamation patterns in triplefins (Pisces: Teleostei: Perciformes: Tripterygiidae). - Tuhinga 16: 137-167.

[23] Jawad, L. A., Al-Jufaili, S. M. (2007): Scale morphology of greater lizardfish Saurida tumbil (Bloch, 1795) (Pisces: Synodontidae). - Journal of Fish Biology 70: 1185-1212. 
[24] Jindal, R., Jha, S. K. (2005): Lepidological and toxicological studies of monocrotophos: An organophosphate pesticide on the scales of Cyprinus carpio var. communis Linnaeus 1758. - Aquacult 6(1): 39-44.

[25] Johal, M. S., Novak, J., Oliva, O. (1984): Notes on the growth of the common carp Cyprinius carpio in Northen India and middle Europe. - Vest. Cs. Spolec. Zool. 48: 2438.

[26] Klingenberg, C. P. (2011): MorphoJ: an integrated software package for geometric morphometrics. - Mol Ecol Resour 11: 353-357.

[27] Kottelat, M., Freyhof, J. (2007): Handbook of European Freshwater Fish. - Kottelat, Cornol and Freyhof, Berlin.

[28] Lippitsch, E. (1990): Scale morphology and squamation patterns in cichlids (Teleostei, Perciformes): a comparative study. - Journal of Fish Biology 37: 265-291.

[29] Mahmoud, U. M., Makkawy, I. A. A., Harabawy, A. S. A. (2005): Scales characyeristics of seven species of genus Lethrinus (Family Lethrinidae) from Red Sea, Egypt. - J. Zool. 44: 545-580.

[30] Masood, Z., Yasmeen, R., Haider, M. S., Lakht-e-Zehra, Tarar, O. M., Mussarat-Ul-Ain, Hameed-Ur-Rehaman, Ullah, U., Ihsan-Ul-Haq, B. M., Hossain, Y. (2015): Comparative studies of the scale characters in four mugilid species (Family Mugilidae; Order Mugiliformes) from Karachi Coast, Pakistan. - Biological Forum - An International Journal 7(1): 410-418.

[31] Mekkawy, I. A. A., Wassi, E. T., Basmidi, A. M. (2011): Scales characteristics of three Lutjanus species (Fam. Lutjanidae) from the Red Sea, Egypt. - J Fish Aquat Sci 6(5): 506-522.

[32] Miranda, R., Escala, C. (2000): Morphological and biometric comparison of the scales of the barbels (Barbus Cuvier) of Spain. - J Morphol. 245: 196-205.

[33] Moneva, C. S. O., Torres, M. A. J., Tabugo, S. R., Demayo, C. G. (2012): Qualitative and geometric morphometric description of the shapes of scales of viridescent parrotfish, Calotomus viridescens (Rüppell, 1835). - The Second International Congress on Interdisciplinary Research and Development, 31 May-1 June 2012, Thailand.

[34] Müller, G.-J. (1958): Scardinius racovitzai n. sp. (Pisces, Cyprinidae), eine reliktäre Rotfeder aus Westrumänien. - Senckenbergiana Biologica 39(3/4): 165-168.

[35] Müller, T., Várkonyi, L., Gagiu, A., Kovács, B., Buza, E., Majoros, G., Staszny, Á., Horváth, Á., Bernáth, G., Tóth, G., Tatár, S., Urbányi, B., Fehér, Z., Grigoras, G., Serban, C., Müllerné, T. M. (2014a): Attempts on ex situ conservation of Melanopsis parreyssii and S. racovitzai. - Book of Abstracts II. Sustainable Development in the Carpathian Basin International Conference, 11-12 December, 2014, Budapest. Szent Istvan University Press, pp. 35-36.

[36] Müller, T., Várkonyi, L., Gagiu, A., Balázs, K., Buza, E., Majoros, G., Staszny, Á., Horváth, Á., Bernáth, G., Tóth, G., Tatár, S., Urbányi, B., Fehér, Z., Grigoras, G., Serban, C., Müllerné, T. M. (2014b): Kísérlet a váradi maradványcsiga (Melanopsis parreysi) és a Racovitza-kele (Scardinius racovitzai) megmentésére. - Book of Abstracts II. Sustainable Development in the Carpathian Basin International Conference, 11-12 December, 2014, Budapest. Szent Istvan University Press, pp. 36-37.

[37] Nico, L., Fuller, P., Jacobs, G., Larson, J., Makled, T. H., Fusaro, A., Neilson, M. (2015): Scardinius erythrophthalmus (Linnaeus, 1758). - U.S. Geological Survey, Nonindigenous Aquatic Species Database, Gainesville, FL. https://nas.er.usgs.gov/queries/FactSheet.aspx?speciesID=648. Accessed on 2/13/2018.

[38] Pillay, T. V. R. (1950): Structure and development of the scales of five species of grey mullets of Bengal. - Proceedings of the National Institute of Sciences of India 17: 413424.

[39] Pou, M. N., Gallego, L. (1990): Metodo para el estudio anatomico de las escamas de los osteichthyes. - Revista Cientifica (IEB) 7: 79-84 (in Spanish). 
[40] Poulet, N., Reyjol, Y., Collier, H., Lek, S. (2005): Does fish scale morphology allow the identification of populations at a local scale? A case study for rostrum dace Leuciscus leuciscus burdigalensis in River Viaur (S W France). - Aquat Sci 67: 122-127.

[41] Renjith, R. K., Jaiswar, A. K., Chakraborty, S. K., Sreekanth, G. B. (2014): Application of scale shape variation in fish systematics - an illustration using six species of the family Nemipteridae (Teleostei: Perciformes). - Indian J Fish 61(4): 88-92.

[42] Rohlf, F. J. (2016a): TpsDig2 version 2.26 (Tps_Digitize). http://life.bio.sunysb.edu/morph/.

[43] Rohlf, F. J. (2016b): TpsUtil version 1.70 (Tps_Utility program). http://life.bio.sunysb.edu/morph/.

[44] Sire, J. Y. (1986): Ontogenetic development of surface ornamentation in the scale of Hemichromis bimaculatus (Cichlidae) J. - Fish Biol. 28: 713-724.

[45] Staszny, Á., Ferincz, Á., Weiperth, A., Havas, E., Urbányi, B., Paulovits, G. (2012): Scale-morphometry study to discriminate gibel carp (Carassius gibelio) populations in the Balaton-catchment (Hungary). - Acta Zool Hung 58(Suppl.): 19-27.

[46] Sudo, S., Tsuyuki, K., Ito, Y., Ikohagi, T. (2002): A study on the surface shape of fish scales. - SME Int. J. Ser. C. 45: 1100-1105.

[47] Tandon, K. K., Johal, M. S. (1996): Age and Growth in Indian Freshwater Fishes. Narendra Publishing House, New Delhi.

[48] Taylor, R. J. (2012): Applications of Fish Scale Analysis to Understand Growth Dynamics of Fish Populations. - PhD Thesis, University of Hull, Hull, UK.

[49] Telcean, C. I., Cupșa, D. (2013): The drastic decline of fish fauna in the thermal lake of Baile 1 Mai (Băile Episcopale, Bihor County, Romania). - Pisces Hungarici 7: 141-142. 